\title{
COASTAL GEOMORPHOLOGICAL FEATURES AND GEOARCHAEOLOGICAL POTENTIAL OF KAVOURI BAY, ATTICA, GREECE
}

\author{
Vandarakis D. ${ }^{1,3}$, Pavlopoulos K. ${ }^{1,2}$, Kapsimalis V. ${ }^{3}$ \\ ${ }^{1}$ Harokopio University, 70 El. Venizelou, Kallithea, 17671, Athens - GREECE \\ (dbandarakis@hua.gr) \\ ${ }^{2}$ Paris-Sorbonne University Abu Dhabi, P.O. Box 38044, AD UAE \\ (kosmas.pavlopoulos@psuad.ac.ae). \\ ${ }^{3}$ Hellenic Centre for Marine Research (HCMR), 46.7 km Athens - Sounio ave., P.O. Box 712, \\ P.C.19013, Anavyssos Greece, (kapsim@hcmr.gr)
}

\begin{abstract}
The discovery of a paved Hellenistic road, which was ended at the shoreline of the Megalo Kavouri bay in Attica, Greece, led the archaeologists to hypothesize that an ancient harbour would be located somewhere at the adjacent submarine area. For the identification of the position of this harbour, a joint submarine and littoral geomorphological survey was carried out. The oceanographic mission was conducted in order to map the underwater landforms. A variety of geomorphological characteristics, types of substrate and habitats (i.e., rocky outcrops, boulder or gravel accumulations etc.) and anthropogenic objects (i.e., debris of recent construction material) were identified in the shallow water seabed of the Kavouri Bay. The littoral geomorphological survey was carried out to determine the natural processes affecting the continental part of the area and map the coastal landscape features. Data derived by both submarine and littoral geomorphological investigations indicate that the most probable location of the harbour could be situated in the southern part of the study area.

Keywords: Littoral geomorphology, submarine geomorphology, bathymetry, Relative Sea Level.

\section{Пєрíi}

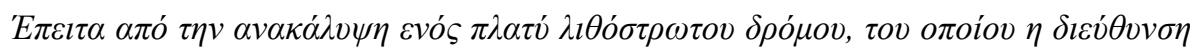

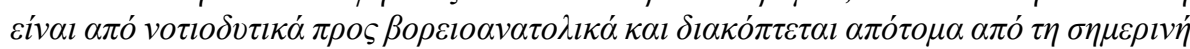

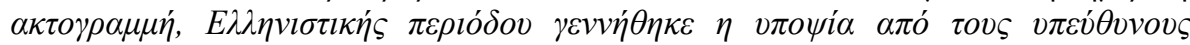

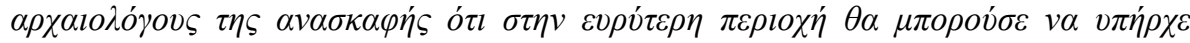

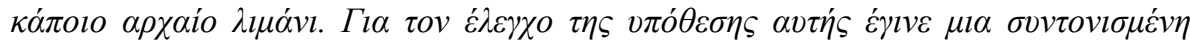

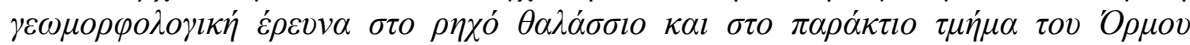

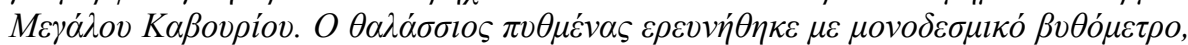

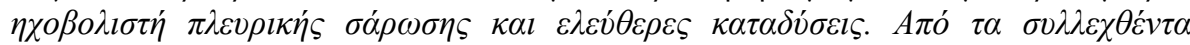

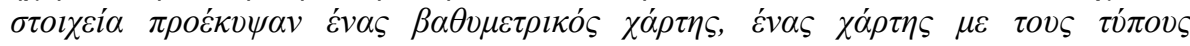

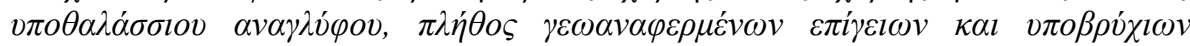

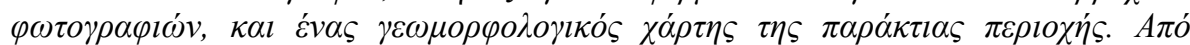

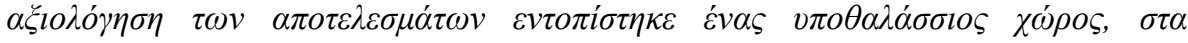




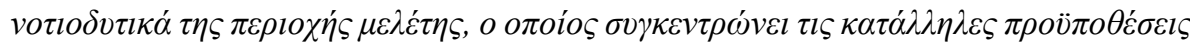

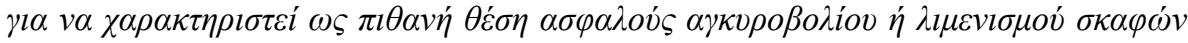

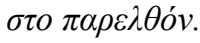

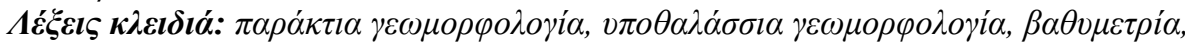

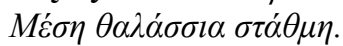

\section{Introduction}

After the unearthing of a long and wide paved Hellenistic road (figure 4) in the coastal area of Megalo Kavouri, Attica, the archaeologists assumed that near this area an ancient harbour may be existed. The discovered road was part of an extended network of commercial roads connecting the settlements of South Attica. It has an NE-SW direction, and is terminated at the modern beach. Archaeologists involved in the excavation suspect that the end of the road is still covered by modern coastal sediments or has been destroyed by marine processes (wave erosion or relative sea level rise). Three institutions (Harokopio University, Hellenic Centre for Marine Research and Euphoria of Underwater Antiquities) were realized a joint geomorphological survey in order to identify potential sites that are suitable to be a safe anchorage or harbour.

The geomorphological survey at the Megalo Kavouri Bay (Figure 1) determined some underwater areas of interest, such as submerged paleoshorelines (beachrocks), bedrock (marls and sandstones) at a depth of $8.5 \mathrm{~m}$, and submerged wave cut platforms at depths of $1.80-2.40 \mathrm{~m}$.

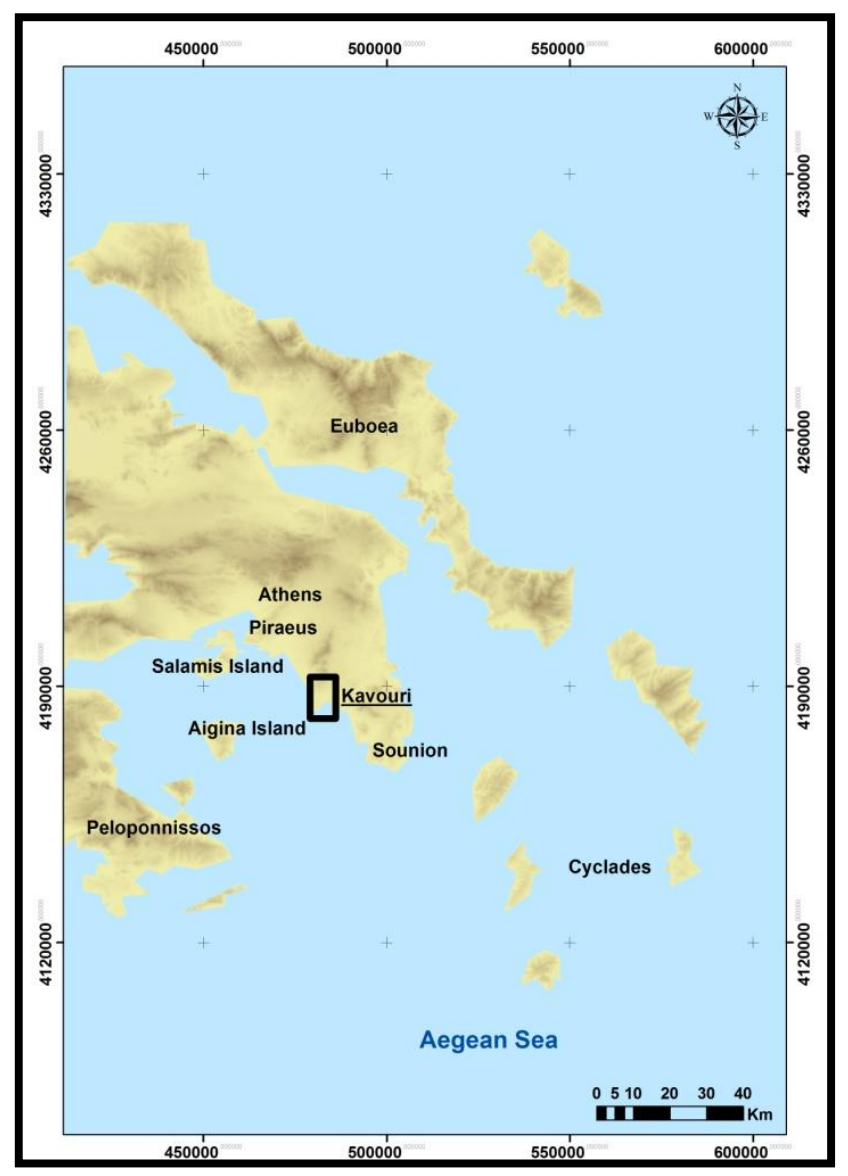

Figure 1 - Location Map of Kavouri area. 


\section{Materials and Methods}

\subsection{Littoral survey}

Littoral geomorphological investigation included the definitive depiction of landforms in the coastal area of Megalo Kavouri. A Digital Elevation Model (resolution pixel of 5x5 m) provided by National Cadastre \& Mapping Agency S.A. was used as topographic background. All features were plotted in ArcGIS (version 10.2) as points, lines or polygons according the methodology and symbology proposed by Pavlopoulos et al. (2009).

\subsection{Underwater survey}

In July 2014 an oceanographic mission was carried out in the Megalo Kavouri Bay by inflatable boat "Triton I" of HCMR. Bathymetric and side imaging data were acquired by a single beam eco sounder (Humminbird, 998c HD SI Combo) using a functional emission frequency of $200 \mathrm{kHz}$ and $450 \mathrm{kHz}$, respectively. During the survey the sea level was $0.72 \mathrm{~m}$ above its mean level, as recorded by Piraeus Port tidal gauge. The selected coordinate system was the WGS84, while the projection system was UTM zone 34N. The bathymetric map was designed by means of ArcGIS (version 10.2), while the post-processing of side-scan echograms and the creation of acoustic mosaic were performed using the SonarTRX software. From the analysis of acoustic mosaic as well as underwater photographs, various morphological features were recognized on the seabed, such as rock outcrops, sediment accumulations (mostly sandy deposits), Posidonia Oceanica meadow and anthropogenic objects of all periods. These maps overlayed on satellite images provided by Google Earth for easier management of the geographic information. Many free dives were realized to collect sediment samples from the seabed and take photographs using an underwater camera (Nikon COOLPIX AW120).

\section{Results}

\subsection{Description of the bathymetric data}

The maximum recorded water depth is $18 \mathrm{~m}$ and is located in the western part of the study area, about $850 \mathrm{~m}$ off the shoreline. The distribution of the contours follows, in general, the orientation of the coastline and the water depth increases towards the northwest. This relatively simple bathymetry is disturbed by the presence of three islands located in the northern, central and southern parts of the study area in the vicinity of the shore. In particular, the central island is sporadically connected, according to the prevailing hydrodynamic conditions, to the neighbouring shore through a sedimentary tombolo (constitute mainly of sand and pebbles). This process has been snapped by a recent satellite image (14 March 2008) of Google Earth. In addition, a small morphological basin has been detected in the southwestern part of the coast, in front of modern jetties at depths between $2 \mathrm{~m}$ and $4.5 \mathrm{~m}$ (Figure 2).

At depths up to 3-4 m, the central beach of the Megalo Kavouri Bay consists of sandy sediments. P articularly, in the nearshore section of the beach (at depths up to $1 \mathrm{~m}$ ), the sand forms two longshor e bars having maximum heights of about $0.5 \mathrm{~m}$. These sedimentary formations are related to the ac tion of local coastal processes (wave and currents) which are conduced to the redistribution of the $\mathrm{s}$ andy sediments. The other parts of the bay (at depths of $<3-4 \mathrm{~m}$ ) consist of coarse sediments (grave 1 , cobbles and boulders) or rock outcrops. In deeper waters (at depths of $>3-4 \mathrm{~m}$ ), there are patches of sand or sandy mud, and extended areas of Posidonia Oceanica covering the soft and hard bedro ck (Figure 3 and 4). 


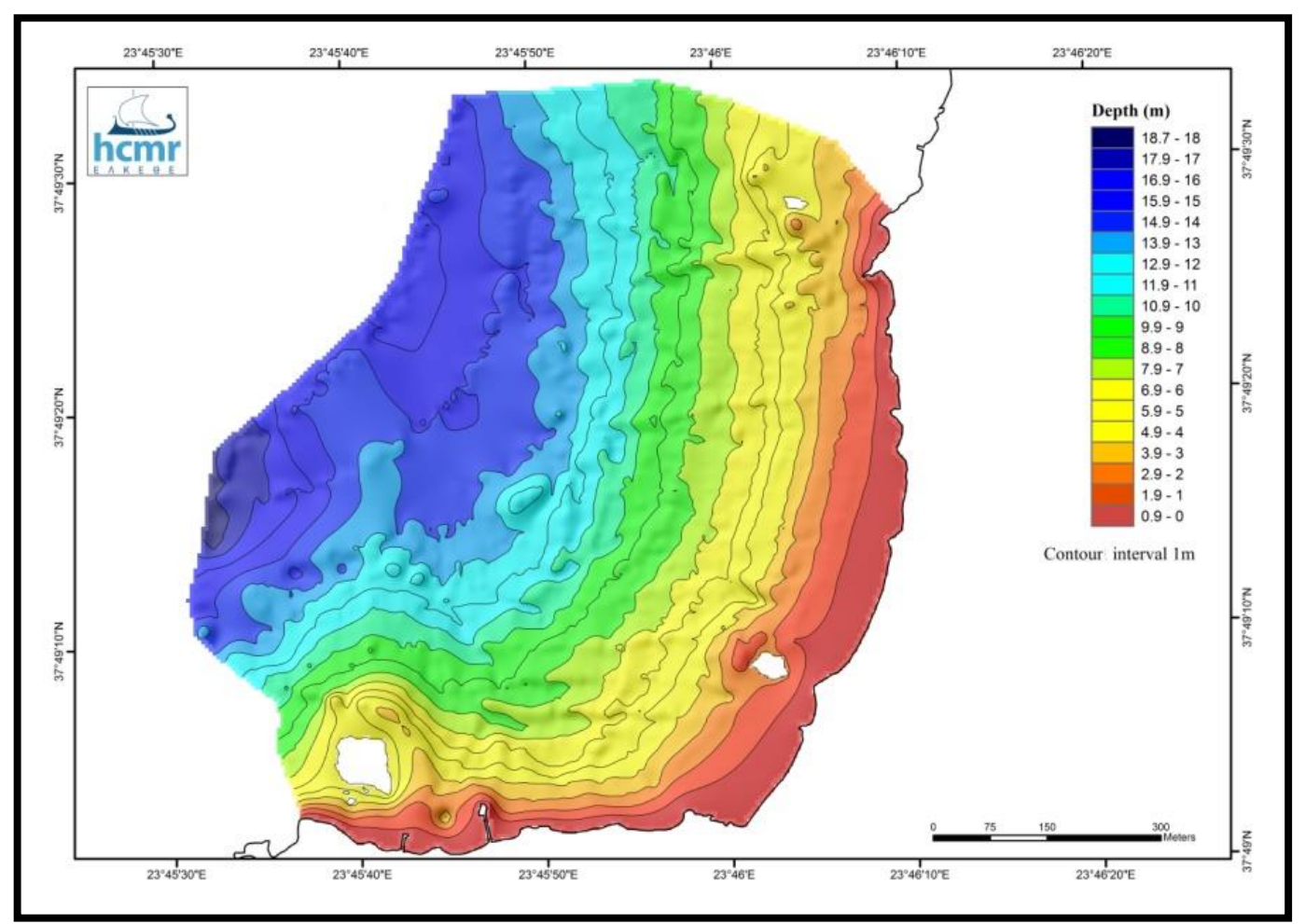

Figure 2 - Bathymetric map, the contours as they appear after their evaluation.

\subsection{Description of the geomorphological map}

The littoral area of Megalo Kavouri presents a diverse coastline, beaches consisting of fine-grained (Kavouri beach) and coarse-grained sediments, and rocky coasts with low (platforms) or high (cliffs) slope (Figure 4).

More specifically, starting from the northern part of the study area (Voula beach) and heading south coast with sand and fine pebbles occurs, which is located behind anthropogenic structure (possibly seawalls) located on the coastal area in front of the beach of Voula. This construction creates wave shade and therefore, not only prevents the erosion of the coast, but also facilitates the deposition of the most fine grains of sediments transported by coastal currents and waves. In the underwater area two rows of beachrocks at depths of 2,40 m (width development $23 \mathrm{~m}$ ) and 4,80 m (width development $20 \mathrm{~m}$ ) were discovered. These submerged shoreline show relatively stable sea level during their creation, but the immersion implies a general and continuous rise in the sea level.

To the south, the slope increases because of the hill Ag. Nikolaos, where, the "Lower Marble" (Marinos et al., 1956; Papakis et al., 1959; Katsavria et al., 1996) is covered by younger marine sediments (Katsavria et al., 1996). As shown in the geomorphological map (Figure 4), the hill acts as a boundary between the coast of Voula and the coast of Kavouri. In the coastal area at the foot of the hill encountered coastal cliffs with an inclination of less than 40 degrees, without deposition, to the coast of Kavouri where coastal cliffs appear with an inclination of less than 40 degrees with sandy sediment. 


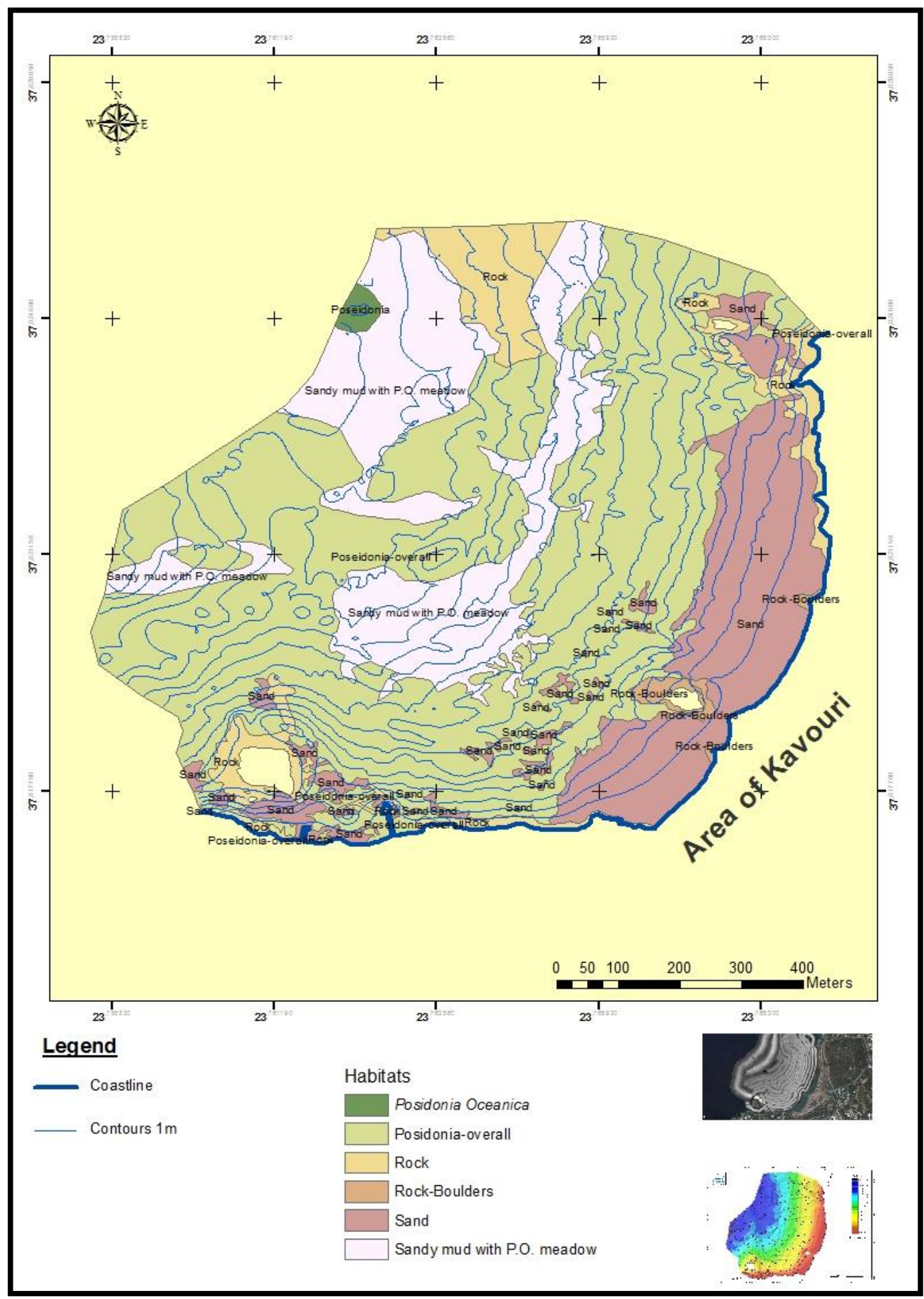

Figure 3 - Mosaic of the recordings, the bathymetric map, Contour map and habitats of the submarine area of Megalo Kavouri bay. 
The coastal area of the Megalo Kavouri Bay consists mostly of sandy sediment that is deposited not only from past terrestrial processes but continues to be deposited by the protection of the small island situated just in front of the Megalo Kavouri Bay. In the underwater part northeast and southwest of the islet spotted submerged sandy barrier whose creation is related to the action of the coastal current, ie the redistribution of the sandy sediments. Shoreline retreat is observed in the northern and southern parts of the Megalo Kavouri Bay, by erosive features such as coastal caves, cliffs more than 40 degrees with sediment etc. (figure 4). In these parts are outcrops of the "Lower Marble" associated with conglomerates and schist (Lepsius, 1893; Papakis et al., 1959; Katsikatsos et al., 1976; Katsavria et al., 1996). In the southern part, there are coastal cliffs with or without sedimentary talus produced by toe failure of the soft-rock slopes. At the southern and western ends of the study area, cliffs occur with gradients over 40 degrees. Among the jetties in the southeastern part of the study area, coastal cliffs with pebbles and coarse-grained debris are observed. In the underwater the seafloor has gentle gradients, much lower than those detected on the terrestrial relief. Also beachrocks can be observed at a depth of $1.20 \mathrm{~m}$, and submerged shore platforms at $1.80 \mathrm{~m}$ and 2.40 $\mathrm{m}$, which could be considered as paleo-shorelines. In this area, the sediment of the seabed is mainly composed by fine-grained sands and fine-grained pebbles.

\section{Discussion-Conclusion}

According to the theoretical eustatic-isostatic model of Lambeck and Purcell (2005) as well as datings measured on material derived from Zea and Mounichia bays (located in the Piraeus peninsula) (Pavlopoulos et al., 2011), the sea level during the Classical / Hellenistic period ( 2400 cal y BP) was $1.6 \mathrm{~m}$ below its present position (Figure 6$)$. The paleo-shoreline might be located in a distance of 10-85 m offshore the present shoreline. Nowadays the Classial / Hellenistic paleoshoreline can be buried under recent sediments in the central part of the research area, and therefore it is not easily detectable. Conversely, in the rest parts of the bay, it is probably at its initial position, since no erosion or deposition occurs.

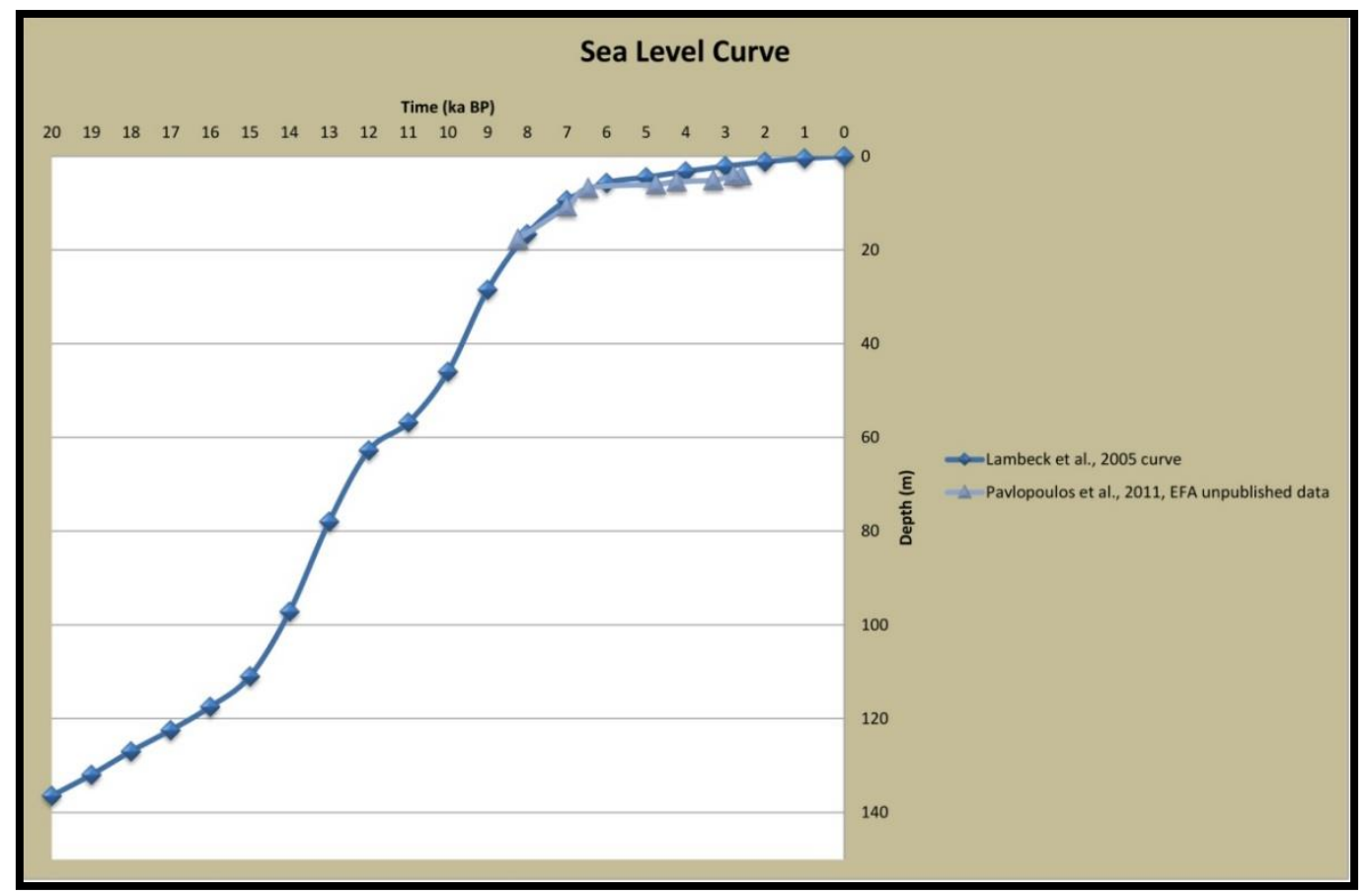

Figure 5 - Comparison of the Sea level curves for the study area. 


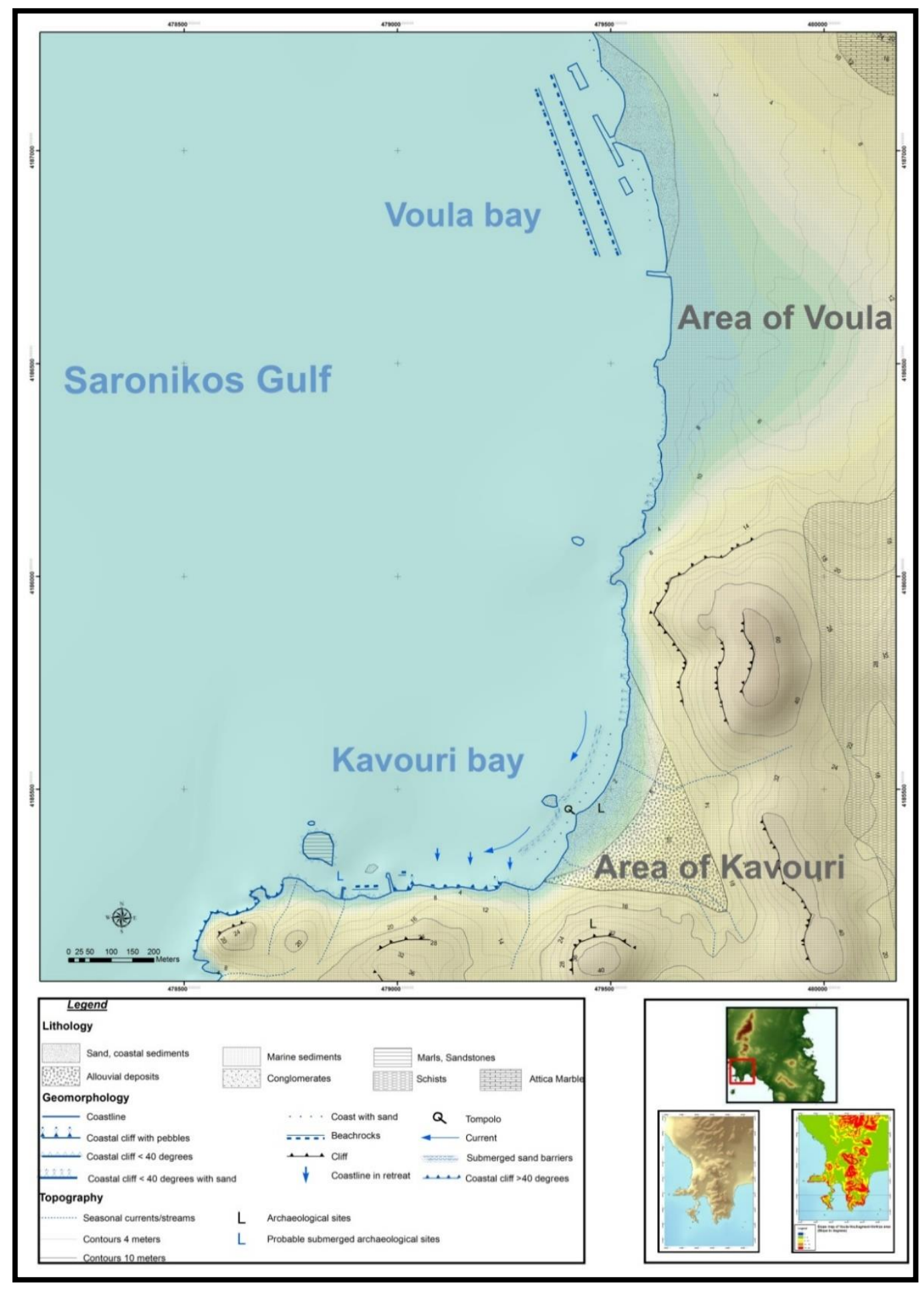

Figure 4 - Geomorphological map, DEM and Slope map of the study area. 


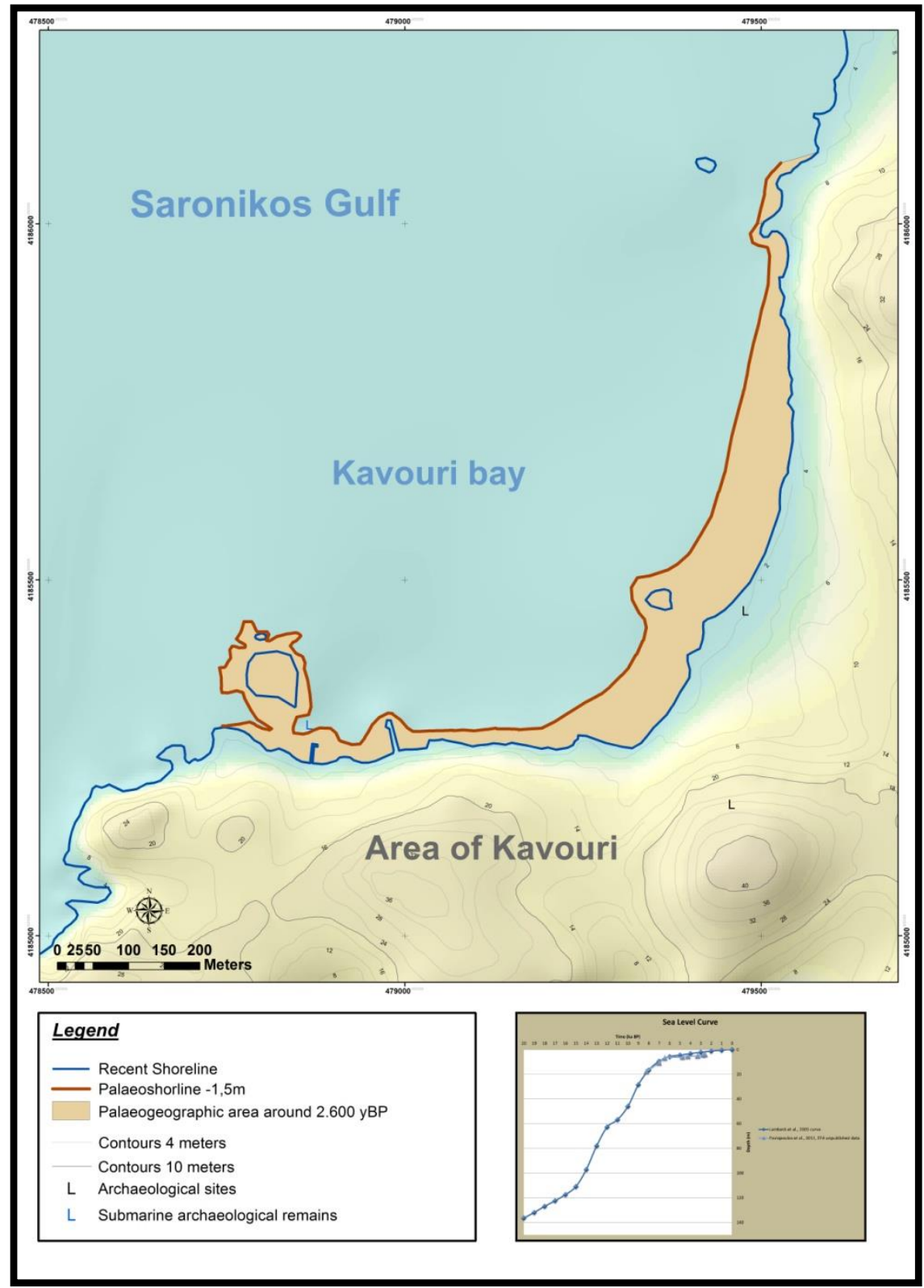

Figure 6 - The contour line of $\mathbf{- 1 , 5} \mathrm{m}$, where the coastline was situated, according to the model of Lambeck et al. (2005), Pavlopoulos et al. (2011), along with EFA unpublished data, around 2400 yBP.

The submarine sedimentary basin located in front of two small jetties in the southwestern part of the study area could be presumably used for mooring or anchoring during the Classical / Hellenistic period, since it is well protected by strong winds and high waves. In addition its bedrock consists of sandy material.

Although submarine survey has not discovered any distinctive geometric target (e.g., building foundations, port facilities, shipwrecks, etc.), there are some findings, such as potsherd which indicate human activities. 
From the coastal and the submarine geomorphological survey, superficial geometric targets (eg buildings bases, port facilities, shipwrecks, etc.) have not been identified. However, due to the geomorphological conformation of the basin located in front of the modern jetties, and the large number of broken pottery remains (found from the free diving geomorphological investigation) located in the southwestern part of the study area, as well as the mild hydrodynamic conditions prevailing there (protection from strong winds and high waves) make the most suitable spot for a harbour or anchorage.

\section{Acknowledgements}

We would like to express our gratitude to the funder of this project mr. Athanasios Martinos, for his contribution and interest in our research.

\section{References}

Goiran, J.P., Pavlopoulos, K., Fouache, E., Triantaphyllou, M. and Etienne, R., 2011. Piraeus, the ancient island of Athens: Evidence from Holocene sediment and historical archives, Geology, 39, 531-534, doi: 10.1130/G31818.1.

Gustavsson, M., 2005. Development of a Detailed Geomorphological Mapping System and GIS Geodatabase in Sweden, Licentiate Thesis.

Gustavsson, M. and Kolstrup, E., 2009. New geomorphological mapping system used at different scales in a Swedish glaciated area, Geomorphology, 110(1-2), 37-44.

Katsavria, N., Rontagianni, Th. and Georgiou, Ch., 1996. Geological research of Vari-Vouliagmeni area, Institute of Geology and Mineral Exloration, Athens (In greek).

Katsikatsos, G., Mercier, J. and Vergely, P., 1976. La fenêtre d' Attique-Cyclades et des fenêtres métamorphiques des Hellenides internes (Grèce), C.R. Acad. Sc. Paris, 283, 1613-1616.

Lambeck, K. and Purcell, A., 2005. Sea-level change in the Mediterranean Sea since the LGM: model predictions for tectonically stable areas, Quaternary Science Reviews, 24(18-19), 1969-1988.

Lepsius, R., 1893. Geologie von Attika. Berlin.

Marinos, G. and Petraschek, W., 1956. Lavrion, Institute of Geology and Mineral Exloration, vol. 4, Athens (In greek).

Papakis, Votelakis and Charalampous, 1959. Report on geological, lithological and hydrological composition of the coast of Saronikos, Institute of Geology and Mineral Exloration, Athens (In greek).

Pavlopoulos, K., 2011. Geomorphology - Introduction in Geosciences, Edit. ION, Athens (In greek).

Pavlopoulos, K., Skentos, A. and Kotambassi, Ch., 2008. Geomorphological mapping and research of the Surounding area of Dispilio - Lake Kastoria, Journal Anaskama, 3, 101-120 (In greek).

Pavlopoulos, K., Evelpidou, N. and Vassilopoulos, A., 2009. Mapping Geomorphological Environments, Springer.

Pavlopoulos, K., Kapsimalis, V., Theodorakopoulou, K. and Panagiotopoulos, I., 2011. Vertical displacement trends in the Aegean coastal zone (NE Mediterranean) during the Holocene assessed by geo-archaeological data, Holocene, 22(6), 717-728. 